\title{
Crustacea (Isopoda, Anomura, Brachyura) from the Cretaceous of Soh area (NW Isfahan) Central Iran
}

\section{Crustacea (Isopoda, Anomura, Brachyura) del Cretácico de la región de Soh (NW de Isfahán) Irán Central}

Ali Bahrami ${ }^{1}$, Mehdi Yazdi ${ }^{1}$, Oscar González-León ${ }^{2,3}$, María de Lourdes Serrano-Sánchez ${ }^{4}$, Francisco J. Vega ${ }^{4, *}$

\begin{abstract}
${ }^{1}$ Department of Geology, University of Isfahan, POB. 81746-73441, Isfahan, I.R. Iran.

${ }^{2}$ Posgrado en Ciencias de la Tierra, Universidad Nacional Autónoma de México, Ciudad Universitaria, Coyoacán, 04510, CDMX, Mexico.

${ }^{3}$ Facultad de Estudios Superiores Iztacala, Universidad Nacional Autónoma de México, Tlalnepantla, 54070, Estado de México, Mexico.

${ }^{4}$ Instituto de Geología, Universidad Nacional Autónoma de México, Ciudad Universitaria, Coyoacán, 04510, CDMX, Mexico.

* Corresponding author: (F. J. Vega)

vegver@unam.mx
\end{abstract}

\section{ABSTRACT}

The second fossil isopod from Iran is herein reported. Additional specimens of the small lobster Huhatanka iranica Bahrami and Vega in Yazdi et al. (2010) are also revised. The aforementioned allows differentiating this species from the only other known species, H. kiowana (Scott, 1970) from the Albian of Kansas, USA. Some indeterminate callianassoids, found associated with the isopod and $H$. iranica, are also reported.

Keywords: Crustacea, Isopoda, Decapoda, Albian, Isfahan, Iran.

\section{RESUMEN}

Se reporta el segundo registro de isópodo fósil para Irán, así como varios ejemplares complementarios de la langosta Huhatanka iranica Bahramiy Vega en Yazdi et al. (2010), lo cual permite diferenciar a esta especie de la otra especie del género, H. kiowana (Scott, 1970) del Albiano de Kansas, USA. Algunos callianassoideos, asociados al isópodo y H. iranica, son reportados.

Palabras clave: Crustacea, Isopoda, Decapoda, Albiano, Isfahán, Irán.

\section{How to cite this article:}

Bahrami, A., Yazdi, M., González-León, O., Serrano-Sánchez, M. L., Vega, F. J., 2020, Crustacea (Isopoda, Anomura, Brachyura) from the Cretaceous of Soh area (NW Isfahan) Central Iran: Boletín de la Sociedad Geológica Mexicana, 72 (2), A271019. http://dx.doi. org/10.18268/BSGM2020v72n2a27 1019
Manuscript received: September 08, 2019

Corrected manuscript received: October 25, 2019

Manuscript accepted: October 30, 2019

Peer Reviewing under the responsibility of Universidad Nacional Autónoma de México.

This is an open access article under the CC BY-NC-SA (https://creativecommons.org/licenses/by-nc-sa/4.0/) 


\section{Introduction}

Cretaceous crustaceans from Iran are relatively scarce and have been reported by Feldmann et al. (2007), Yazdi et al. (2009, 2010), and McCobb and Hairapetian (2009). The present contribution reports the first isopod from late Albian deposits of central Iran, represented by a single, posterior molt specimen, attributed to Natatolana sp. Additional specimens of the mecochirid Huhatanka iranica Bahrami and Vega in Yazdi et al. (2010), from the late Albian of Soh area, allow describing some morphological details lacking in the first report by Yazdi et al. (2010). These new specimens are compared with the type specimens of H. kiowana (Scott, 1970) from the Albian of Kansas, described by Feldmann and West (1978).

\section{Geology and stratigraphy}

The Iranian Plate, a major segment of the Cimmerian microcontinent, had detached from northeastern Gondwana by the end of Permian and collided with the Turan Plate (part of Eurasia) towards the end of the Triassic (Sengore, 1990; Stampfli et al., 1991; Saidi et al., 1997; Mirnejad et al., 2013). From the Early Jurassic to Senonian, the young Neo-Tethyan oceanic basin was reduced in extent by its subduction under the Iranian continental plate. The final closure of the Neo-Tethys, marked by the collision between the Iranian and Arabian plates, took place during the Neogene (Berberian et al., 1982; Shahabpour, 2005; Ahmadi Khalaji et al., 2007). The Iranian plateau is divided into several zones from SW to NE (Figure 1): Zagros fold-thrust belt, Sanandaj-Sirjan metamorphic zone, Urumieh-Dokhtar volcanic belt, central Iran zone, Alborz zone, Kopeh Dagh zone, and Eastern Iran zone (Falcon, 1967; Stocklin, 1968; Dewey et al., 1973; Stocklin and Nabavi, 1973; Jackson and McKenzie, 1984; Sengore, 1984; Byrne et al., 1992; McCall, 2002; Blanc et al., 2003; Alavi, 2004; Walker and Jackson, 2004).
The study area is located in Central Iran (Figure 1). Following the late Cimmerian orogeny, the Early Cretaceous sea advanced onto the small continent of Central Iran, the transgression in the Soh area began in the late Barremian and continued to the early Albian (Zahedi, 1973). A sequence of thick sediments eroded by this uplift included several lithologies such as red conglomerate, sandstones, and limestones (Yazdi et al., 2010). Orbitolina gray limestones with marl intercalations are late Aptian in age (Khodaverdi et al., 2016) (Figures 2 and 3). Shales with intercalations of limestone contain ammonites, green to gray marly limestone with nodules that include Huhatanka iranica, the here described isopod, small turritellid gastropods; and nuculid bivalves (De Grave, 2009). Thick, micritic Turonian limestones overlie the crustacean beds (Figure 3). The youngest sequence (Eocene and Oligo-Miocene, Qom Formation) can be observed anywhere in the plain (Khodaverdi et al., 2016). An angular unconformity is present between the

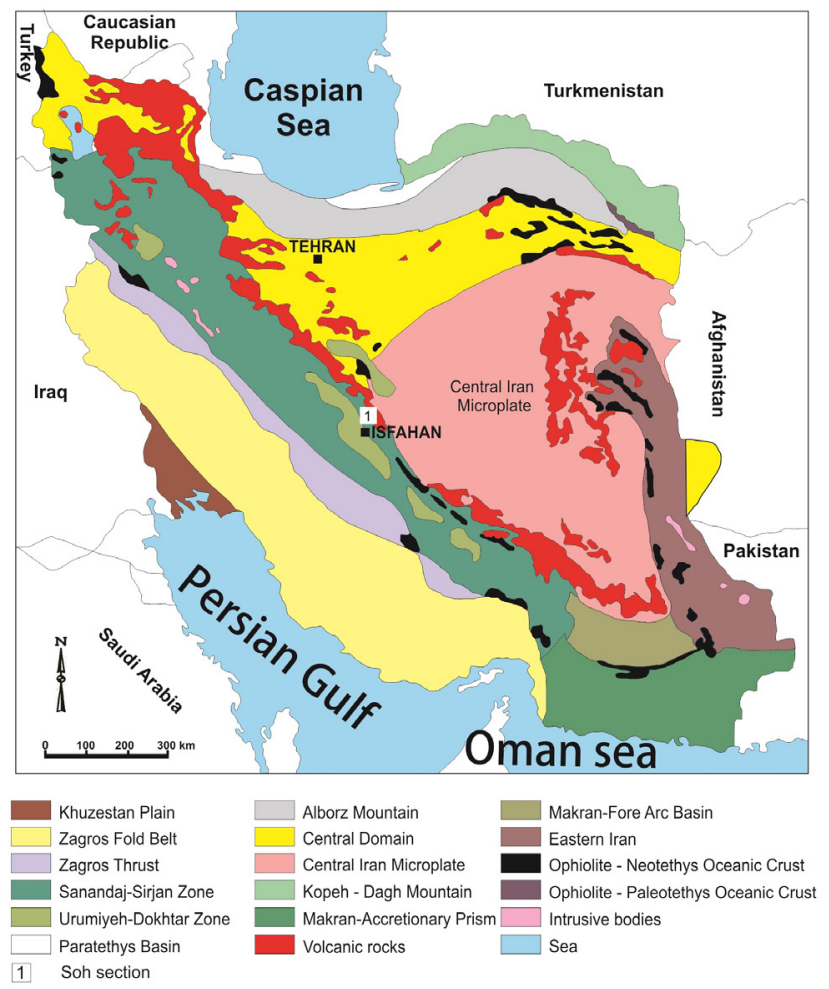

Figure 1 Structural map of central Iran (modified from Bahrami et al., 2018). 
Pliocene and the Pleistocene (clastic and travertine), and different ages below this sequence can be traced throughout the area. This angular unconformity is a result of the final alpine orogenic phase. The studied section (Figures 3, 4) is located near the village of Soh $(70 \mathrm{~km}$ northwest of Isfahan) and is accessible by a $35 \mathrm{~km}$ unpaved road off the Isfahan-Tehran highway. The section is on the right side of a seasonal river valley. Coordinates for the fossil locality are N $33^{\circ} 279^{\prime \prime}$, E $51^{\circ} 2832$ ". Structurally, the locality belongs to the Central Iran microplate, which is restricted by the NWSE Sanandaj-Sirjan metamorphic belt to the west, and by the Great Kavir fault to the East.Specimens reported here are held in the Department of Geology, Faculty of Sciences, University of Isfahan, 81746, Iran, under acronym IUMC, and in the paleontological collection of Kent State University (KSU), Kent, Ohio (USA).

\begin{abstract}
Abbreviations: $a=$ branchiocardiac groove, $a c=$ antennal carina, $b=$ antennal groove, $b 1=$ hepatic groove, $c=$ postcervical groove, $c d=$ cardiac groove, $e 1 e=$ cervical groove, $e n=$ endopod, $e x$ = exopod, $g c=$ gastro-orbital carina, $m c=$ median carina, $o c=$ orbital carina, $P 1-P 5=$ pereiopods 1-5, $s 1-s 6=$ pleonal somites (i-v in Figure 5), $T e=$ telson, $V I I-V=$ pereonal somites in Figure 5.
\end{abstract}

\section{Systematic palaeontology}

Class Malacostraca Latreille, 1802

Order Isopoda Latreille, 1817

Suborder Cymothoida Wägele, 1989

Family Cirolanidae Dana, 1853

Genus Natatolana Bruce, 1981

Type species: Cirolana hirtipes H. Milne

Edwards, 1840, by original designation, not

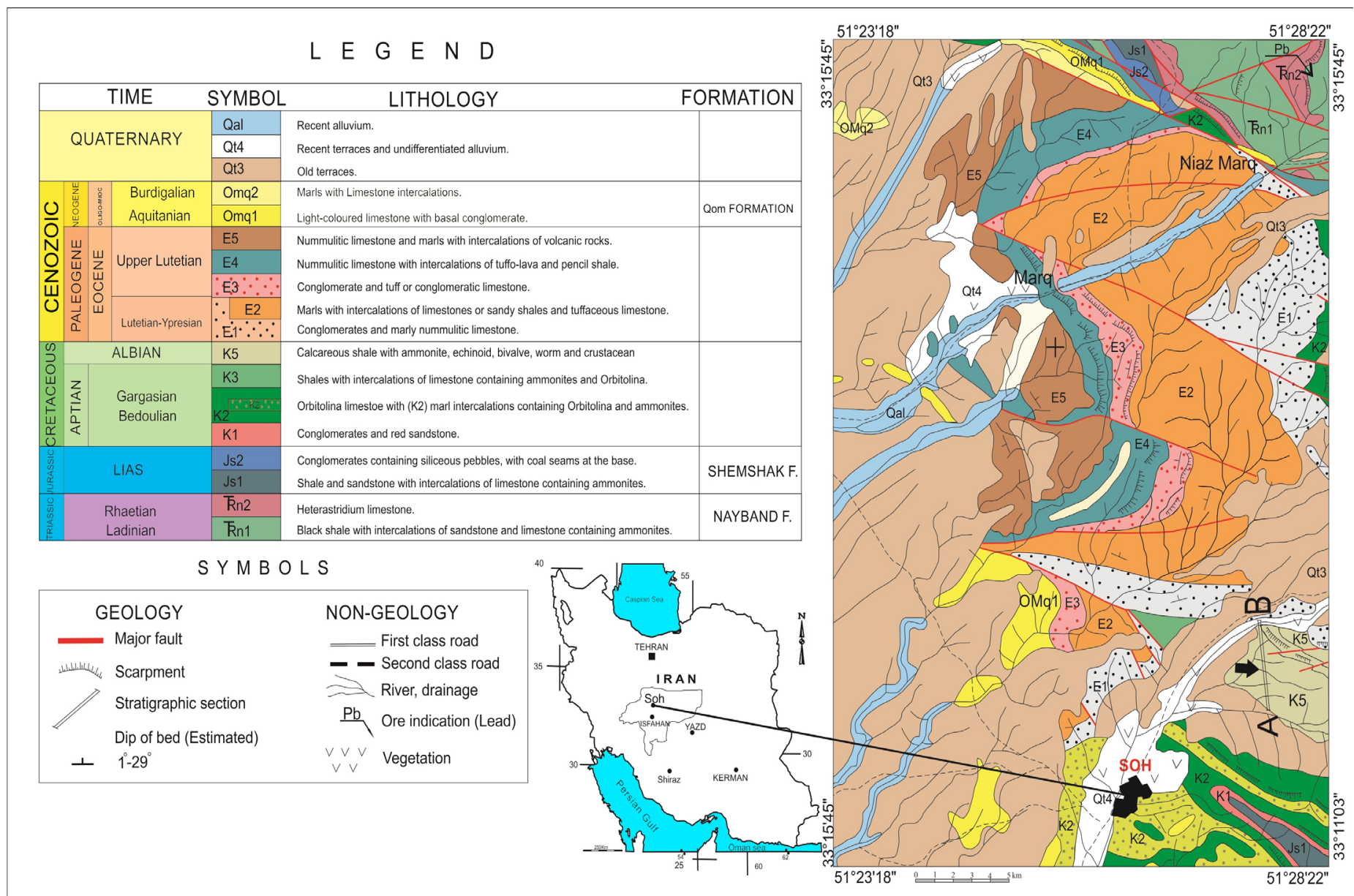


subsequent designation as stated by

Brusca et al. (1995).

Natatolana sp.

Figure $5 \mathrm{~A}$ to $5 \mathrm{C}$

Description: Small posterior exuvia, smooth, preserving pereonites $\mathrm{V}-\mathrm{VII}$, pleonites $\mathrm{i}^{-} \mathrm{v}$, pleotelson, left pereopod 7 and uropods. Pereonites V-VII semirectangular, represent less than half the maximum length and maximum width, all of about same length and width. Pleon represents about one third the maximum length and about two thirds the maximum width; pleonites with
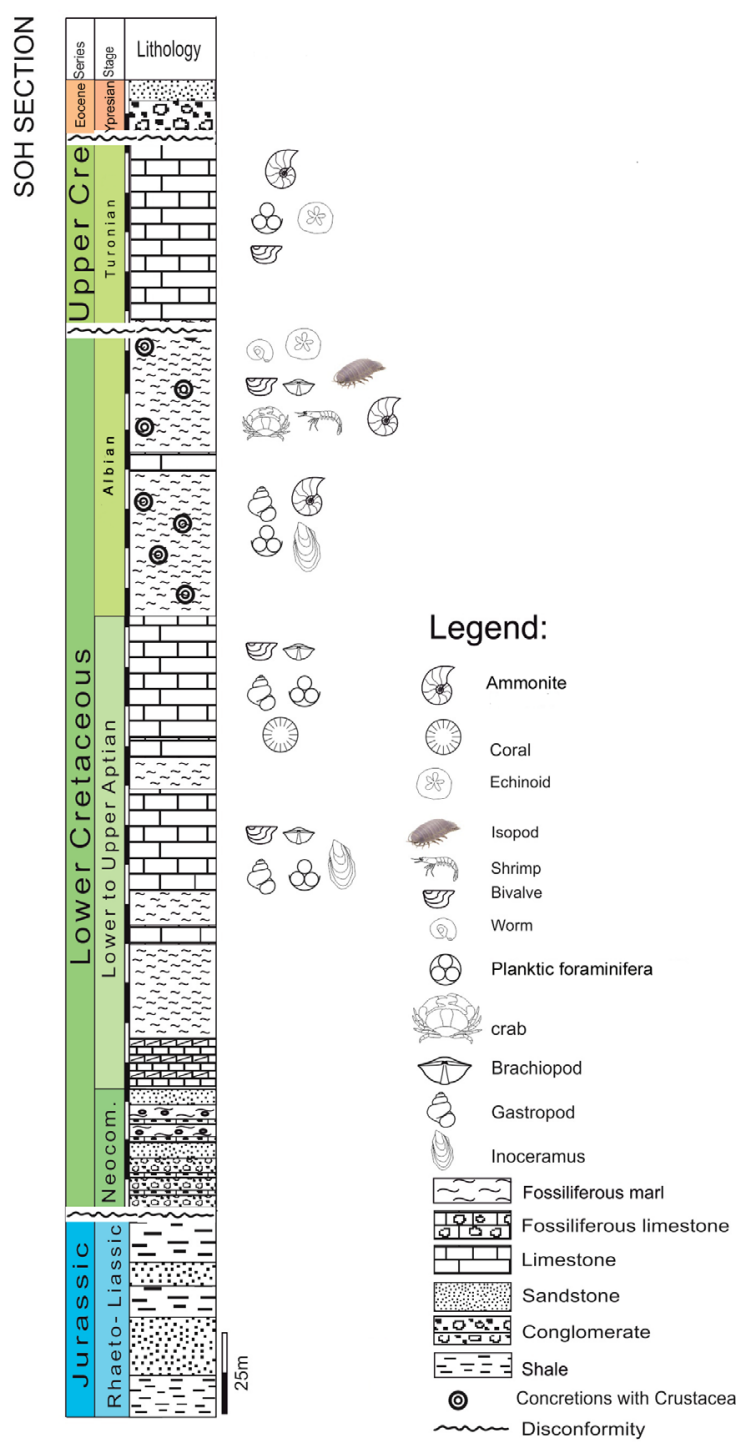

Figure 3 Stratigraphic section of the study area, indicating position of reported specimens. triangular, acute posterolateral margins. Pleotelson sub-triangular, two-thirds the maximum length and half the maximum width, with rounded posterior margin. Left pereopod 7 incompletely preserved, only propodus and acute dactylus. Uropods wide, peduncle apparently narrow; exopod narrow, lanceolate, about half the length of endopod and one-third its maximum width; margins smooth; endopod wide, subovate, rounded margins, extend to level of posterior tip of pleotelson.

Material: One specimen, IUMC-100.

Measurements: length $=15.3 \mathrm{~mm}$, width $=9.4$ mm.

Discussion: The specimen represents the second record for a fossil isopod from Iran. Recently Hyžný et al. (2019) reinterpreted crustacean remains thought to be lobster remains from the Early Cretaceous of Iran (Feldmann et al., 2007). Other similar cirolanid representatives reported from Cretaceous, Paleogene, and Neogene deposits around the world include Cymothoidana websteri Jarzembowski et al. (2014) from the Hauterivian-Barremian of China, Spain, and the United Kingdom. More recently, Vega et al. (2019) reported undetermined cirolanid isopods from the Early Cretaceous of Puebla, Mexico, associated with posterior exuviae of Natatolana poblana Bruce and Vega (2019, in Vega et al., 2019), which differs from the studied specimen in having smaller and narrower uropods. Additional and more complete Iranian specimens could confirm if they represent a new or already known species of Natatolana.

Order Decapoda Latreille, 1802

Suborder Pleocyemata Burkenroad, 1963

Infraorder Glypheidea Zittel, 1885

Superfamily Glypheoidea Zittel, 1885

Family Mecochiridae Van Straelen, 1924

Genus Huhatanka Feldmann and West, 1978

Type species: Squilla? kiowana (Scott, 1970), by subsequent designation of Feldmann and West (1978).

Huhatanka iranica Bahrami and Vega in Yazdi et al., 2010

Figures 6A, 6B, and 7 
Huhatanka iranica Bahrami and Vega in Yazdi et al. (2010), p. 209, fig. 3.1-3.4.

Emended diagnosis: Small mecochirid, cephalothorax elongate, longer than high; posterior margin rimmed, curved; surface uniformly granulate; rostrum triangular, short; relatively weak median carina with fine tubercles extending from posterior portion of rostrum to cervical groove; a pair of parallel carinae extend from the lateral sides of rostrum to cervical groove; antennal region onethird carapace length, with three longitudinal carinae; cervical groove deep; oblique weak carina extends from dorsal portion of carapace on lower portion of cervical groove; postcervical, branchiocardiac, and hepatic grooves shallow; cardiac groove slightly deep; tubercles become finer on posterolateral side of carapace; s1 covered by granules; P1 slightly longer than P2-P5.

Emended description: Mecochirid of small size; carapace elongate, maximum height two thirds of maximum length, posterior margin rounded, rimmed, surface covered by relatively uniform tubercles; rostrum acute, triangular, bordered by finely granulate ridges that extend posteriorly to cervical groove; weaker median ridge also extends from tip of rostrum to cervical groove; antennal region one third the carapace length, with three granulate longitudinal carinas, middle and lower carinas stronger; cervical groove deep, inclined toward anterolateral margin; oblique weak ridge extends from dorsal portion of carapace to lower portion of cervical groove; branchiocardiac, hepatic and postcervical grooves shallow and parallel; cardiac groove slightly deep; tubercles become finer on posterolateral side of carapace, s1 and s2 similar size and shape; surface covered by granules; P1 longer than P2-P5, P2-P5 similar size an length.

Material: IUMC-101 to IUMC-105.

Measurements: IUMC-101, length $=61.2 \mathrm{~mm}$, width $=8.9 \mathrm{~mm}$; IUMC-102, length $=53.1 \mathrm{~mm}$, width $=7.9 \mathrm{~mm}$; IUMC-103, length $=42.3 \mathrm{~mm}$, width $=7.8 \mathrm{~mm}$; IUMC-104, length $=55.5 \mathrm{~mm}$, width $=10.9 \mathrm{~mm}$; IUMC-105, length $=38.8 \mathrm{~mm}$, width $=8.7 \mathrm{~mm}$

Discussion: The specimens confirm the differences previously suggested by Yazdi et al. (2010) between Huhatanka iranica and H. kiowana (Scott,

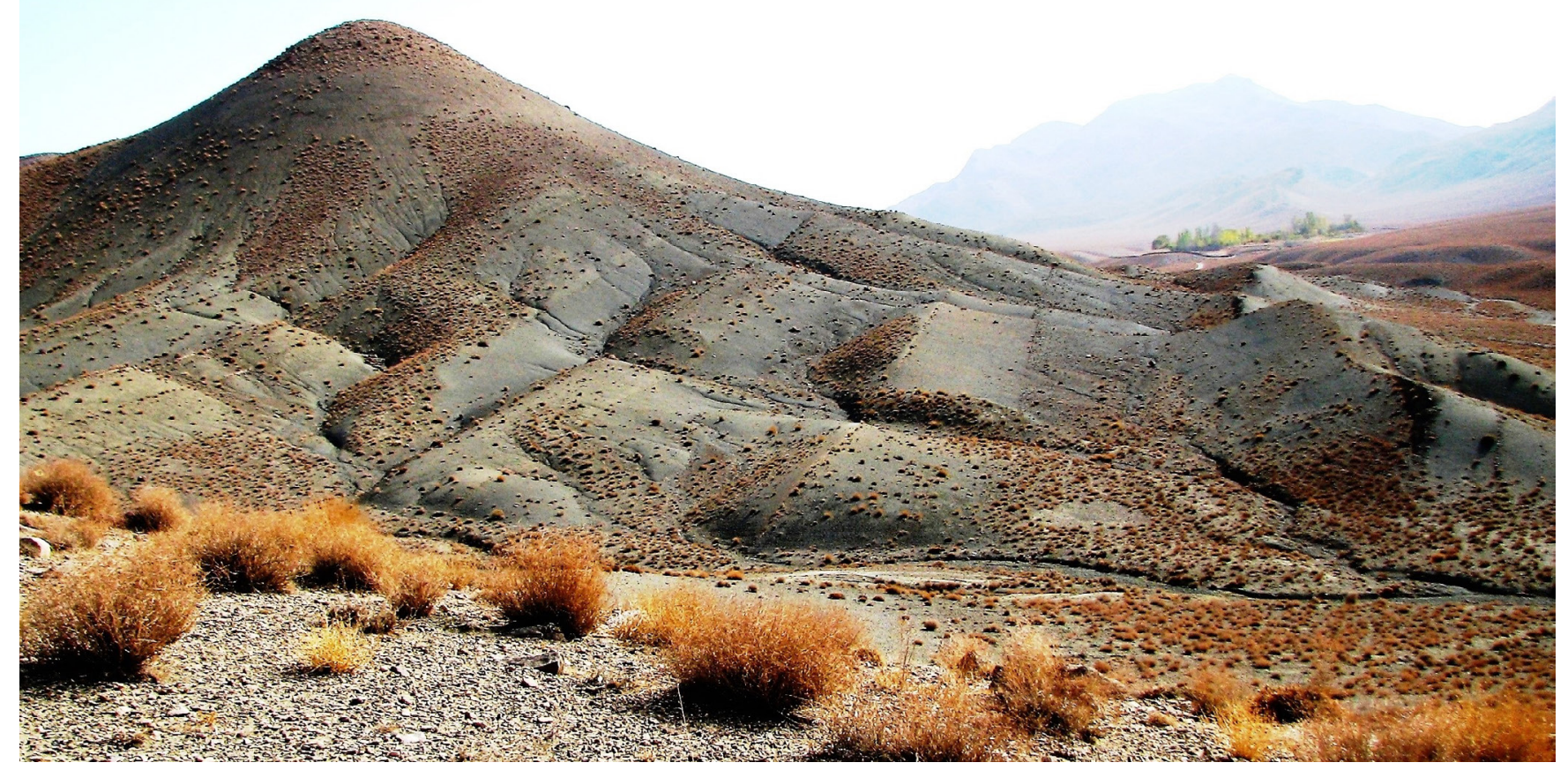

Figure 4 Panoramic view of the Albian greenish shales with nodular concretions containing Crustacea. 
1970). It is clear that the specimens from the Albian of Iran have a more granulose carapace and pleonal surface, showing some morphological features as branchiocardiac, cardiac, and postcervical grooves not previously recognized by Yazdi et al. (2010).

Some of these features were considered weak or absent by Feldmann and West (1978) in their description of the genus. However, the specimens illustrated in Figure $6 \mathrm{E}$ to $6 \mathrm{H}$ show weakly the morphological features previously mentioned. According to Schweitzer et al. (2010) seven genera, Huhatanka (Feldmann and West, 1978), Jabaloya (Garassino et al., 2009), Mecochirus (Germar, 1827), ?Praeatia (Woodward, 1868), Pseudoglyphea (Oppel, 1861), ?Selenisca (Meyer, 1847), and Meyeria (M'Coy,
1849), now Atherfieldastacus (M'Coy, 1849) belong to the Mecochiridae Van Straelen, 1924.

However, Charbonnier et al. (2013) considered Selenisca as a junior synonym of Glyphea. This systematic treatment was confirmed by Chabonnier et al. (2015) from a phylogenetic analysis. Breton et al. (2015) described Meyeria houdardi and Meyeria sp. from the Albian strata east of the Paris Basin and Pays de Bray. However, we consider that the specimens described by Breton et al. (2015, fig. 1A-G, p. 58) show morphological features in the carapace and pleon more similar to Huhatanka than to Meyeria. Recently, Robin et al. (2016) suggested that Jabaloya aragonensis Garassino et al. (2009) has morphological features similar to those of Meyeria. Including some morphological features which are

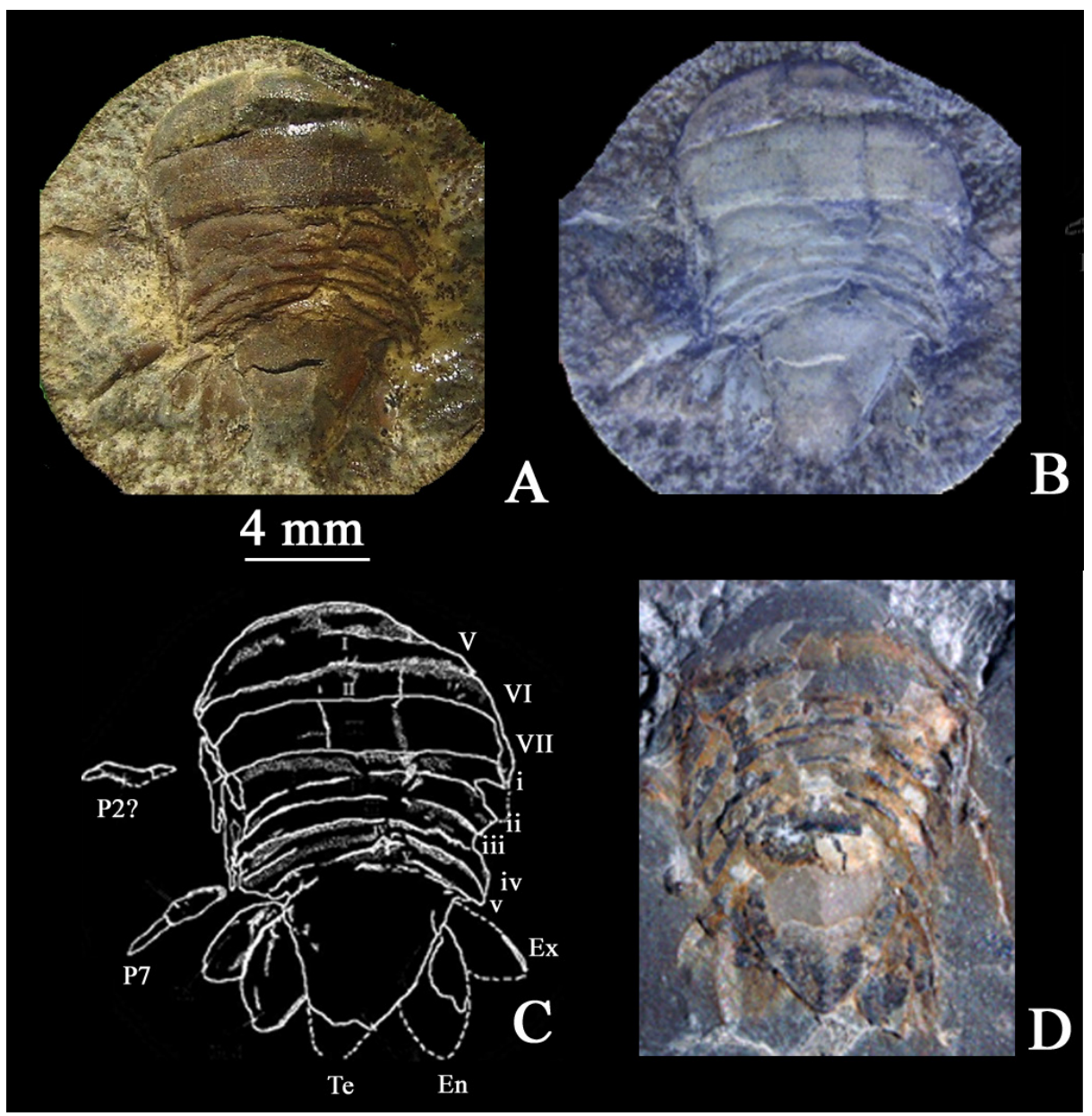

Figure 5 (A-C) Natatolana sp. (IUMC-100) from the late Albian in Central Iran. (A) Image, (B) inverted colour image, and (C) drawing of the almost complete posterior exuvia. (D) Comparison with posterior exuvia of Cirolana pueblaensis Vega and Bruce, 2019 in Vega et al., 2019, holotype IGM-11178, from the Early Cretaceous of Puebla, Mexico. 


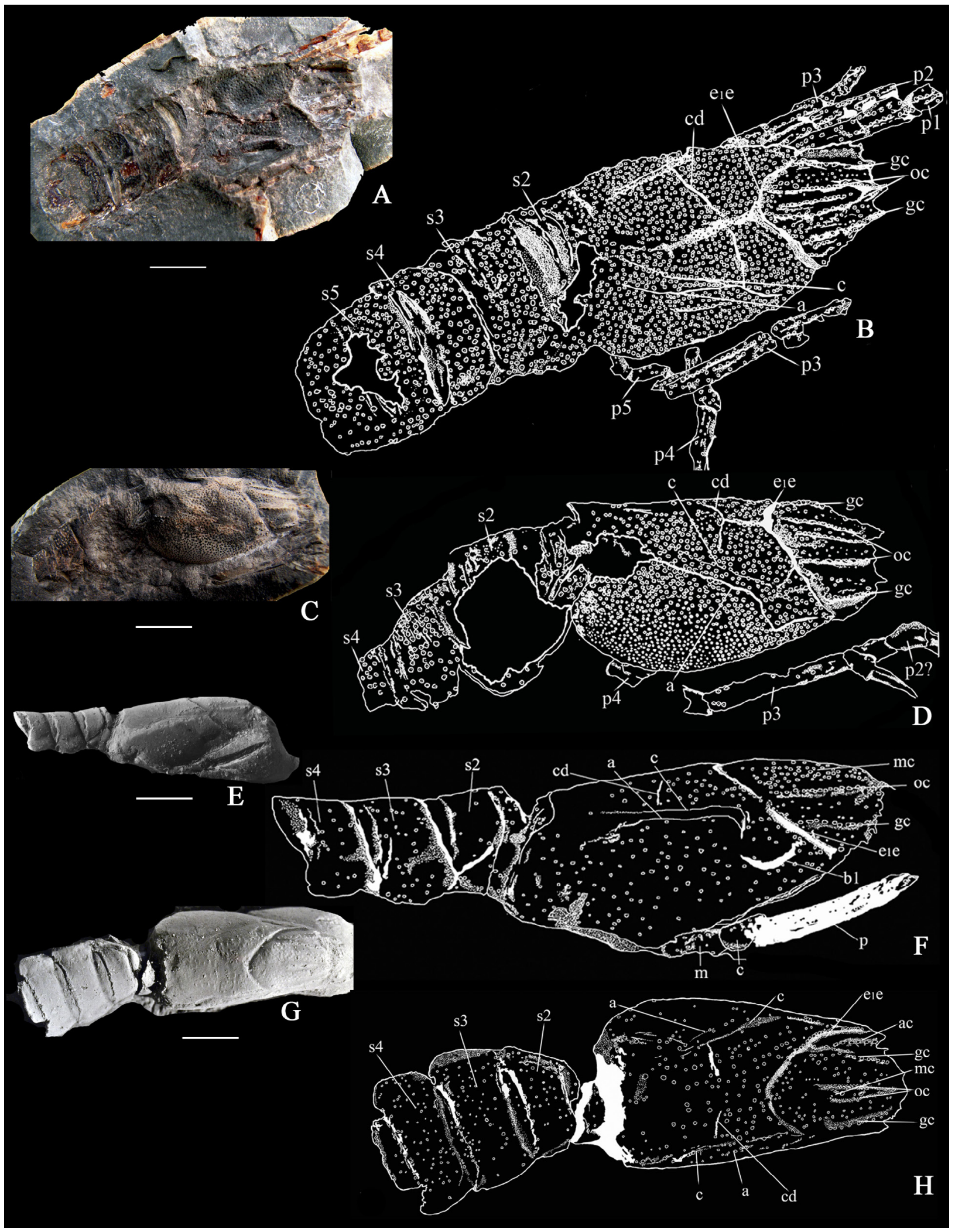

Figure 6 (A-D) Images and drawings of specimens of Huhatnka iranica Yazdi, Bahrami and Vega, 2010 from the Albian of Iran (IUMC 101 and IUMC-102). (E-H) Images and drawings of specimens of Huhatnka kiowana (Scott, 1970) from the Albian of Kiowa Formation, Kansas, USA (KSU 3768). Scale bars $=5 \mathrm{~mm}$. 

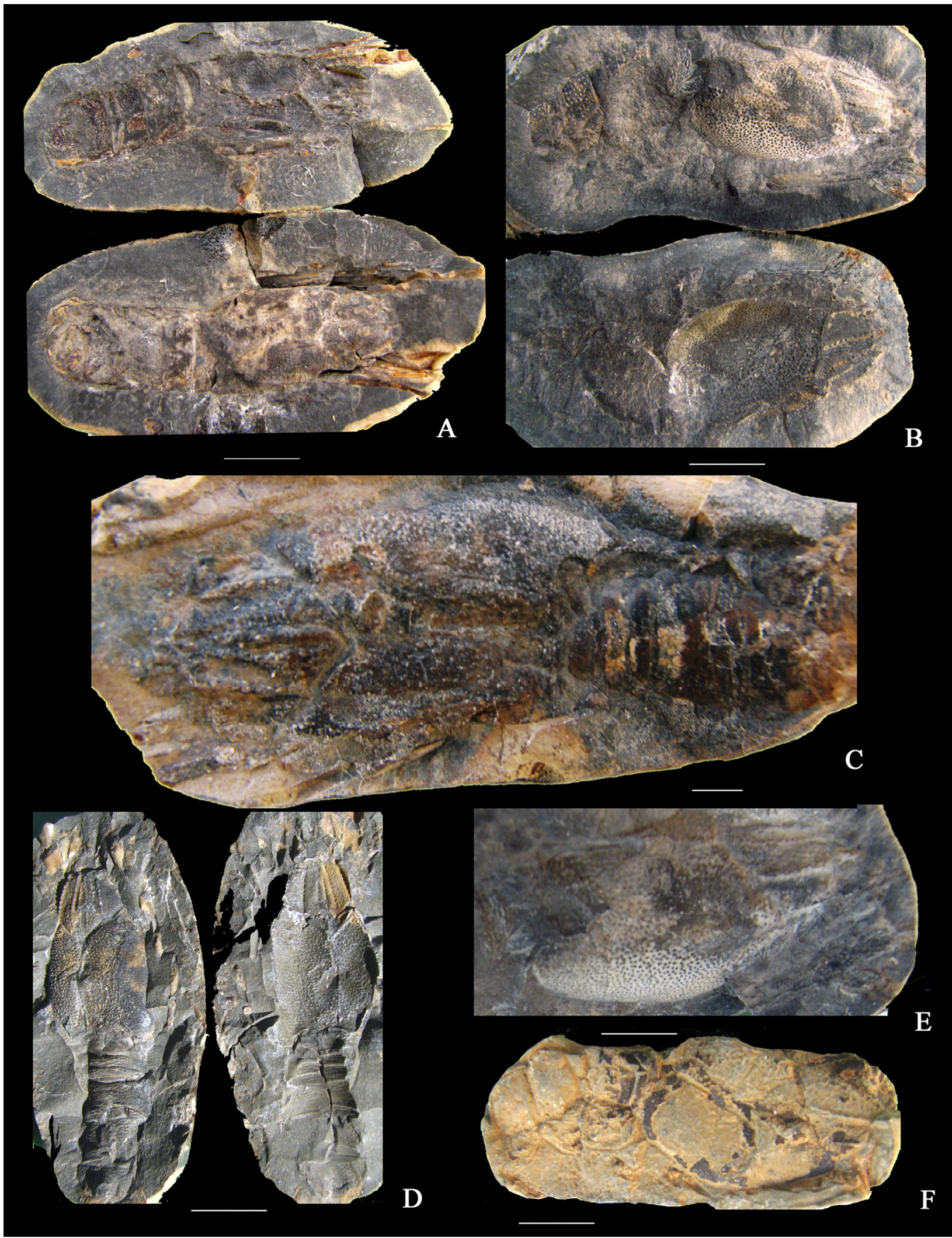

Figure 7 (A-F) Several specimens (part and counterpart) of Huhatnka iranica Yazdi, Bahrami and Vega, 2010 from the Albian of Iran (IUMC-101 to IUMC-105). Scale bars $=5 \mathrm{~mm}$. 


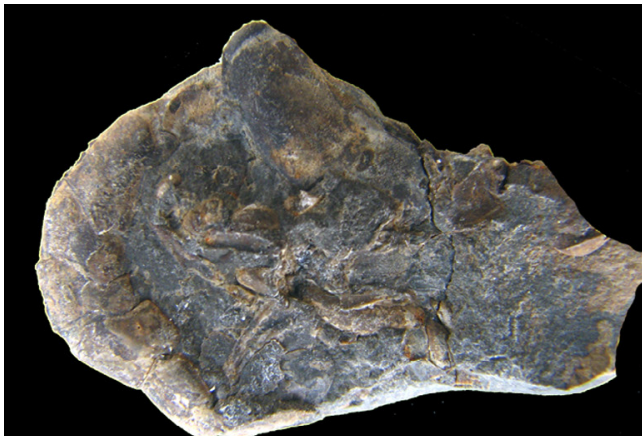

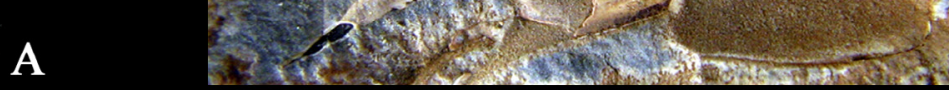
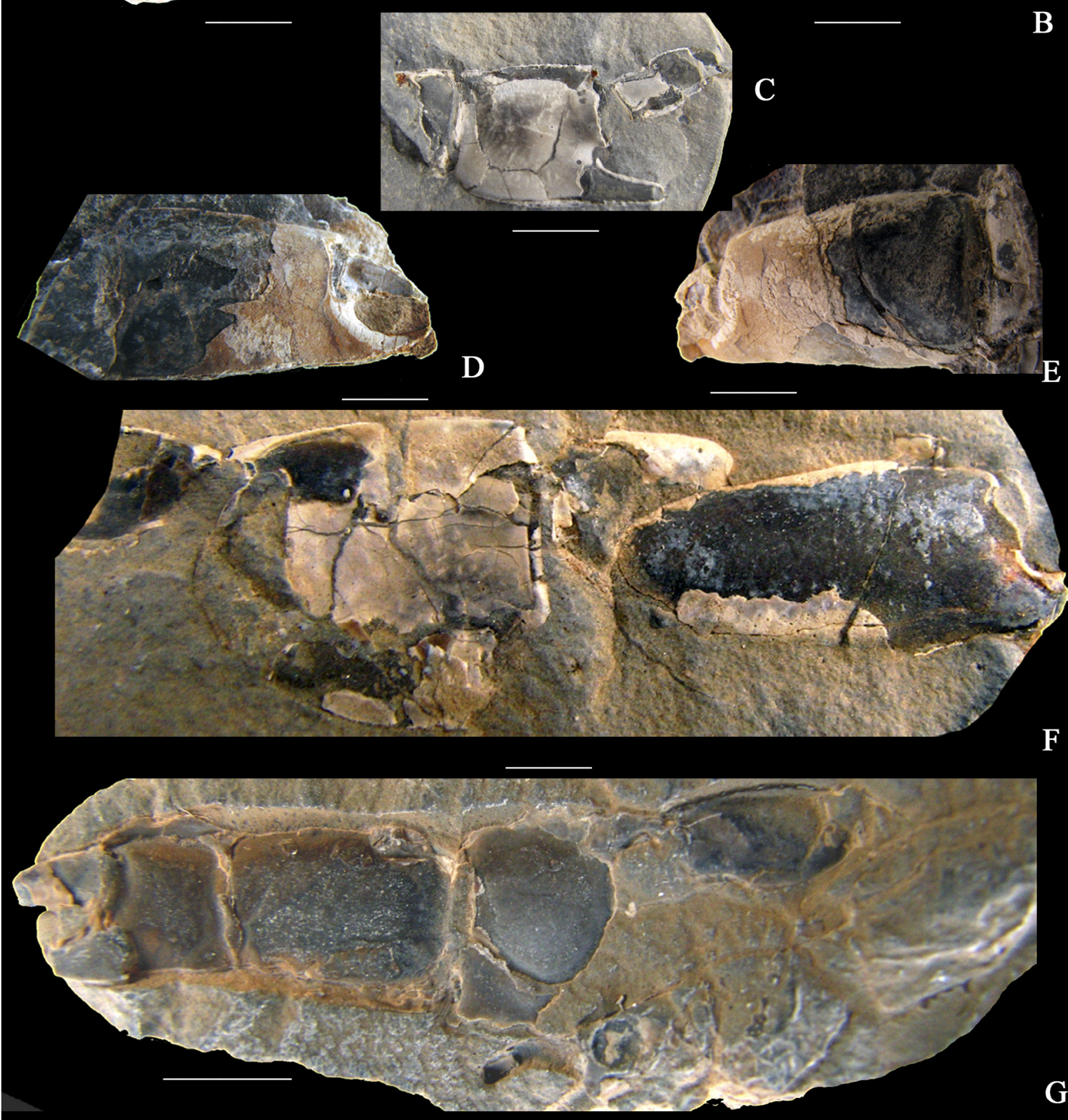

Figure 8 (A-G) Several indeterminate callianassoid specimens from the Albian of Iran (IUMC-106 to IUMC-111). Scale bars $=5 \mathrm{~mm}$. 
absent or modified in Meyeria and Mecochirus, Robin et al. (2016) assigned the new genus Atherfieldastacus within the Mecochiridae, suggesting the new combinations Atherfieldastacus magnus (M'Coy, 1849), A. mexicanus (Rathbun, 1935), A. rapax (Harbort, 1905), and $A$. schwartzi (Kitchin, 1908) for these species previously assigned to Meyeria. Based upon this combination, González-León et al. (2014) considered that Meyeria pueblaensis should be a junior synonym of Meyeria magna (now A. magnus).

\section{Infraorder Thalassinidea Latreille, 1831 \\ Superfamily Callianassoidea Dana, 1852 \\ Family Callianassidae Dana, 1852 \\ Genus and species indet.}

Figure 8

Description: Major cheliped one-third larger than minor cheliped; palm of major cheliped subrectangular, highest near junction with carpus, smooth; dactylus triangular, one-third the length of palm and its width one-fifth the maximum palm height. Merus of minor cheliped subovate, narrower at junction with carpus; carpus subrectangular, twice as high as long, posterior margin curved; palm subrectangular elongate, one-third longer than high; fixed finger triangular, half the length of palm and one-fourth its height.

Material: UIC 3762 to EUIC 3766.

Measurements: EUIC 3762 left cheliped (merus + carpus + palm) length $=36.2 \mathrm{~mm}$, height $=$ $10.3 \mathrm{~mm}$; EUIC 3763 left chela (merus + carpus) length $=18.5 \mathrm{~mm}$, height $=9.8 \mathrm{~mm} ;$ EUIC 3764 right palm length $=16.4 \mathrm{~mm}$, height $=9.6 \mathrm{~mm}$; EUIC 3765 right palm length $=22.1 \mathrm{~mm}$, height $=12.2 \mathrm{~mm}$; EUIC 3766 left palm length $=19.4$ $\mathrm{mm}$, height $=11.5 \mathrm{~mm}$.

Discussion: Yazdi et al. (2009) reported Callianassoidea palm remains from the Albian of Kolah Qazi section - Beudanticeras shale, Central Iran. It is possible that these callianassoid remains are similar to those herein reported, but only complete and better-preserved material could solve the systematic assignment of the specimens left in open nomenclature.

\section{Conclusion}

The new crustacean specimens collected from the Albian beds of Iran expand our knowledge of the crustacean assemblage of this region, including the first record of a fossil isopod. Aptian-Albian outcrops with concretions are potentially important for future findings, including potential new genera and species.

\section{Acknowledgements}

The authors are grateful to the Vice Chancellor for Research and Technology at the University of Isfahan, Iran for financial and logistic support. Our sincere gratitude to Dr. Rodney M. Feldmann, Kent State University, for sharing some images. We are in debt with Salvador Vázquez (BSGM) for his valuable editorial support.

\section{References}

Ahmadi Khalaji, A., Esmaeily, D., Valizadeh, M.V., Bonab, R.H., 2007, Petrology and geochemistry of the granitoid complex of Boroujerd, Sanandaj-Sirjan Zone, Western Iran: Journal of Asian Earth Sciences, 29(56), 859-877. https://doi.org/10.1016/j. jseaes.2006.06.005

Alavi, M., 2004, Regional stratigraphy of the Zagros fold-thrust belt of Iran and its proforeland evolution: American Journal of Science, 304(1), 1-20. https://doi. org/10.2475/ajs.304.1.1

Bahrami, A., Königshof, P., Boncheva, I., Yazdi, M., Khalaji, M., Zarei, E., 2018, Conodont biostratigraphy of the Kesheh and Dizlu sections, and the age range of the Bahram Formation in Central Iran: Palaeobiodiversity and Palaeoenvironments, 98, 315-329. https://doi.org/10.1007/ s12549-017-0307-y 
Blanc, E.J.-P., Allen, M.B., Inger, S., Hassani, H., 2003, Structural styles in the Zagros Simple Folded Zone, Iran: Journal of the Geological Society, 160(3), 401-412. https://doi. org/10.1144/0016-764902-110

Berberian, F., Mure, I.D., Pankhurst, R.J. Berberian, M., 1982, Late Cretaceous and early Miocene Andean-type plutonic activity in northern Makran and central Iran: Journal of the Geological Society London, 139(5), 605-614. https://doi.org/10.1144/ gsjgs. 139.5.0605

Breton, G., Néraudeau, D., Dépré, E., 2015, Mecochiridae (Crustacea, Decapoda, Glypheidea) de l'Albien et du Cénomanien de France: Annales de Paléontologie, 101(1), 55-64. https://doi.org/10.1016/j. annpal.2015.01.001

Bruce, N.L., 1981, Redescription of the isopod (Crustacea) family Phoratopodidae: Beaufortia, 31, 107-110.

Brusca, R.G., Wetzer, R., France, S.C., 1995, Cirolanidae (Crustacea Isopoda Flabellifera) on the Tropical Eastern Pacific: Proceedings of the San Diego Society of Natural History, 30, 1-96.

Burkenroad, M.D., 1963, The evolution of the Eucarida, (Crustacea, Eumalacostraca), in relation to the fossil record: Tulane Studies in Geology, 2(1), 3-17.

Byrne, D.E, Sykes, L.R., Davis, D.M., 1992, Great thrust earthquakes and aseismic slip along the plate boundary of the Makran subduction zone: Journal of Geophysical Research Solid Earth, 97(B1), 449-478. https://doi. org/10.1029/91jb02165

Charbonnier, S., Garassino, A., Schweigert, G., Simpson, M., 2013, A worldwide review of fossil and extant glypheid and litogastrid lobsters (Crustacea, Decapoda, Glypheoidea): Mémoires du Muséum National d'Histoire Naturelle, 205, 1-304.

Charbonnier, S., Audo, D., Barriel, V., Garassino, A., Schweigert, G., Simpson, M., 2015, Phylogeny of fossils and extant glypheid and litogastrid lobsters (Crustacea, Decapoda) as revealed by morphological characters:
Cladistics, 31(3), 231-249. https://doi. org/10.1111/cla.12088

Dana, J.D., 1852, Conspectus Crustaceorum and Conspectus of the Crustacea of the Exploring Expedition under Capt. C. Wilkes, U.S.N. Macroura: Proceedings of the Academy of Natural Sciences of Philadelphia, 6, 10-28.

Dana, J.D., 1853, Crustacea. United States Exploring Expedition During the Years 1838, 1839, 1840, 1841, 1842. Under the Command of Charles Wilkes 14: 696-805, atlas, pls. 46-53.

De Grave, S., Pentcheff, N.D., Ahyong, S.T., Chan, T.-Y., Crandall, K.A., Dworschak, P.G., Felder, D.L., Feldmann, R.M., Fransen, C.H.M., Goulding, L.Y.D., Lemaitre, R., Low, M.E.Y., Martin, J.W., Ng, P.K.L., Schweitzer, C.E., Tan, S.H., Tshudy, D., Wetzer, R., 2009, A classification of living and fossil genera of decapod crustaceans: Raffles Bulletin of Zoology (Suppl. 21), $1-109$.

Dewey, J.F., Pitman, W.C. III, Ryan, W.B.F., Bonnin, J., 1973, Plate tectonics and the evolution of the alpine system: Geological Society of America Bulletin, 84(10), 3137-3180. https://doi.org/10.1130/00167606 (1973)8 4<3137:PTATEO>2. 0 . $\mathrm{CO} ; 2$

Falcon, N.L., 1967, The geology of the northeast margin of the Arabian basement shield: Advancement of Science, 24, 31-42. Feldmann, R.M., Schweitzer, C.E., 2012, What ever happened to Selenisca (Decapoda)?: Bulletin of the Mizunami Fossil Museum 38, 9-14.

Feldmann, R.M., West, R.R., 1978, Huhatanka, a new genus of lobster (Decapoda: Mecochiridae) from the Kiowa Formation (Cretaceous: Albian) of Kansas: Journal of Paleontology, 52, 1219-1226.

Feldmann, R.M., Kolahdouz, A., Biranvand, B., Schweigert, G., 2007, A new family, genus and species of lobster (Decapoda: Achelata) from the Gadvan Formation 
(Early Cretaceous) of Iran: Journal of Paleontology, 81(2), 405-407. https://doi. org/10.1666/0022-3360(2007)81 [405:anfga s]2.0.co;2

Garassino, A., Artal, P., Pasini, G., 2009, Jabaloya aragonensis n. gen., n. sp. (Crustacea, Decapoda, Mecochiridae) and Cedrillosia jurassica n. gen., n. sp. (Crustacea, Decapoda, Glypheidae) from the Upper Jurassic of Teruel Province (Aragón, Spain): Atti della Società Italiana di Scienze Naturali e del Museo Civico di Storia Naturale di Milano, 150(II), 197-206.

Germar, E.F., 1827, Über die Versteinerungen von Solenhofen. Keferstein's Deutschland geognostisch-geologisch Dargestellt, 4, 89-112.

González-León, O., Moreno-Bedmar, J.A., Vega, F.J., 2014, Morphology and ontogeny of the fossil lobster Meyeria magna M'Coy, 1849 (Astacidae, Mecochiridae) from the Lower Cretaceous (Lower Aptian) of Mexico, United Kingdom and Spain: Neues Jahrbuch für Geologie und Palaeontologie Abhandlungen, 271(1), 49-68. https://doi. org/10.1127/0077-7749/2014/0376

Harbort, E., 1905, Die Fauna der SchaumburgLippèschen Kreidemulde: Abhandlungen der Preussischen Geologischen Landesanstalt, neue Folge 14, 10-22.

Hyžný, M., Audo, D., Feldmann, R.M., Schweigert, G., 2019, Tricarina gadvanensis is an isopod: reinterpretation of an alleged lobster from the Lower Cretaceous of Iran: Journal of Paleontology, 1-7. https://doi. org/10.1017/jpa.2019.61

Jackson, J.A., McKenzie, D., 1984, Active tectonics of the Alpine-Himalayan Belt between western Turkey and Pakistan: Geophysical Journal of the Royal Astronomical Society, 77(1), 185-264. https://doi.org/10.1111/ j.1365-246x.1984.tb01931.x

Jarzembowski, E.A., Wang, B., Fang, Y., Zhang, H., 2014, A new aquatic crustacean (Isopoda: Cymothoida) from the early Cretaceous of southern England and comparison with the Chinese and Iberian biotas: Proceedings of the Geologists Association, 125(4), 446-451. http://doi.org/10.1016/j. pgeola.2014.08.001

Khodaverdi Hassan-vand, M., Bahrami, A., Yazdi, M., Ossó, À., Safari, A., Martínez, J.L., Vega, F., 2016, Occurrence of Retrocypoda almelai Via Boada, 1959 (Decapoda: Retroplumidae) in the Eocene of Central Iran: Paleontología Mexicana, 5(1), 21-31.

Kitchin, F.L., 1908, The invertebrate fauna and palaeontological relations of the Uitenhage series: Annals of the South African Museum, 7, 212-268. https://doi.org/10.5962/bhl. title.26289

Latreille, P.A., 1802, Histoire naturelle, générale et particulière des Crustacés et des Insectes. Ouvrage faisant suite à l'histoire naturelle générale et particulière, composée par Leclerc de Buffon, et rédigée par C.S. Sonnini, membre de plusieurs sociétés savantes. Familles naturelles des genres, 3, 467 pp. Paris (Dufart). https://doi.org/10.5962/bhl. title. 15764

Latreille, P.A., 1817, Les crustacés, les arachnides et les insects, in Cuvier, G. (ed.), Le règne animal distribute d'après son organization, pour server de base à l'histoire naturelle des animaux et d'introduction à l'anatomie compare, edition 1, vol. 3: Déterville, Paris, $653 \mathrm{p}$.

Latreille, P.A., 1831, Cours d'entomologie, ou de l'histoire naturelle des Crustacés, des Arachnides, des Myriapodes et des Insectes, etc. Annales I. Atlas. Roret, Paris. 26 pp.

McCall, G.J.H., 2002, A summary of the geology of the Iranian Makran, in Clift, P.D., Kroon, F.D., Gaedecke, C., Craig, J. (eds.), The Tectonic and Climatic Evolution of the Arabian Sea Region: Special Publication of the Geological Society, 195(1), 147-204. https://doi.org/10.1144/gsl. sp.2002.195.01.10

McCobb, L.M.E., Hairapetian, V., 2009, A new lobster Paraclytia valashtensis (Crustacea, Decapoda, Nephropidae) from the Late 
Cretaceous of the central Alborz Range, Iran: Paläontologische Zeitschrift, 83(3), 419-430. https://doi.org/10.1007/ s12542-009-0033-5

M'Coy, F., 1849, On the classification of some British fossil Crustacea, with notices of new forms in the University Collection at Cambridge: The Annals and Magazine of Natural History, 4(23), 330-335. https://doi. org/10.1080/03745486009494843

Meyer, H. Von., 1847, Halycine and Litogaster, zwei Crustaceen-Gattungen aus dem Muschelkalke Württembergs: Palaeontographica, 1, 134-140.

Milne-Edwards, H., 1840, Histoire Naturalle des Crustaces 3. 1-638. Paris: Roret.

Mirnejad, H., Lalonde, A.E., Obbeid, M., Hassansadeh, J., 2013, Geochemistry and Petrogenesis of Mashhad Granitoid: An Insight into the Geodynamic History of Paleo-Tethys in Northeast of Iran: Lithos, 170, 105-116. https://doi.org/10.1016/j. lithos.2013.03.003

Oppel, A., 1861, Die Arten der Gattungen Glyphea und Pseudoglyphea:Jahreshefte des Vereins für Vaterländische Naturkunde in Württemberg, 17, 108-111.

Rathbun, M.J., 1935, Fossil Crustacea of the Atlantic and Gulf Coastal Plain, Geological Society of America Special Paper, 2, 1-160. https://doi.org/10.1130/spe2-p1

Robin, N., Charbonnier, S., Merle, D., Simpson, M., Petit, G., Fernandez, S., 2016, Bivalves on mecochirid lobsters from the Aptian of the Isle of Wight: snapshot on an Early Cretaceous palaeosymbiosis: Palaeogeography, Palaeoclimatology, Palaeoecology, 453, 10-19. https://doi. org/10.1016/j.palaeo.2016.03.025

Saidi, A., Brunet, M.F., Ricou, L.E., 1997, Continental accretion of the Iran Block to Eurasia as seen from Late Paleozoic to Early Cretaceous subsidence curves: Geodinamica Acta, 10, 189-208. https://doi.org/10.1080 /09853111.1997.11105302
Schweitzer, G.E., Feldmann, R.M., Garassino, A., Karasawa, H., Schweigert, G., 2010, Systematic List of Fossil Decapod Crustacean Species: Crustacea Monographs, 10, 1-230. https://doi.org/10.1163/ ej.9789004178915.i-222

Scott, R.W., 1970, Paleoecology and paleontology of the Lower Cretaceous Kiowa Formation, Kansas: Kansas, U.S.A., The University of Kansas Paleontological Contributions, 52, $1-94$.

Sengore, A.M.C., 1984, The Cimmeride Orogenic System and the Tectonics of Eurasia: Geological Society of America Special Paper, 195, 1-82. https://doi.org/10.1130/spe 195

Sengore, A.M.C., 1990, A new model for the late Palaeozoic-Mesozoic tectonic evolution of Iran and implications for Oman, in Robertson, A.H.F., Searle, M.P., Ries, A.C. (eds.), The Geology and Tectonics of the Oman Region: Geological Society of London, Special Publications, 49(1), 797-831. https://doi.org/10.1144/gsl. sp.1992.049.01.49

Shahabpour, J., 2005, Tectonic evolution of the orogenic belt in the region located between Kerman and Neyriz: Journal of Asian Earth Sciences, 24(4), 405-417. https://doi. org/10.1016/j.jseaes.2003.11.007

Stampfli, G., Marcoux, J., Baud, A., 1991, Tethyan margins in space and time: Palaeogeography, Palaeoclimatology, Palaeoecology, 87(1-4), 373-409. https:// doi.org/10.1016/0031-0182(91)90142-e

Stocklin,J., 1968, Structural history and tectonics of Iran: a review: The American Association of Petroleum Geologists, Bulletin, 52(7), 12291258. https://doi.org/10.1306/5d25c4a5$16 \mathrm{c} 1-11 \mathrm{~d} 7-8645000102 \mathrm{c} 1865 \mathrm{~d}$

Stocklin, J., Nabavi, M.H., 1973, Tectonic Map of Iran 1:2500000: Geological Survey of Iran.

Van Straelen, V., 1924, Contribution à l'étude des crustacés décapodes de la Période Jurassique: Brussels: Mémoires de l'Académie Royale de Belgique, Classe des Sciences, series 2, 462 p. 
Vega, F.J., Bruce, N.L., González-León, O., Jeremiah, J., Serrano-Sánchez, M.L., Alvarado-Ortega, J., Moreno-Bedmar, J.A., 2019, Lower Cretaceous marine isopods (Isopoda: Cirolanidae, Sphaeromatidae) from the San Juan Raya and Tlayúa formations, Puebla, Mexico: Journal of Crustacean Biology, 39(2), 121-135. https:// doi.org/10.1093/jcbiol/ruy107

Wägele, J.W., 1989, Evolution und phylogenetisches System del Isopods. Stand der Forschung und neue Erkenntnisse: Zookogica (Stuttgart), 140, 1-262.

Walker, R., Jackson, J., 2004, Active tectonics and late Cenozoic strain distribution in central and eastern Iran: Tectonics, 23(5), 1-24. https://doi.org/10.1029/2003tc001529

Woodward, H., 1868, Fourth report on the structure and classification of the fossil
Crustacea: Report of the British Assocation of Advancement of Science, 72-75.

Yazdi, M., Bahrami, A., Vega, FJ., 2009, Albian decapod Crustacea from Southeast Isfahan, Central Iran-Kolah-Qazi area: Bulletin of the Mizunami Fossil Museum, 35, 71-77.

Yazdi, M., Bahrami, A., Vega, F.J., 2010, Additions to Albian (Cretaceous) Crustacea from Iran: Boletín de la Sociedad Geológica Mexicana, 62(2), 207-211. https://doi.org/10.18268/ bsgm2010v62n2al

Zahedi, M., 1973, Ètude gèologique de la règion de Soh (W de l'Iran Central): Geological Survey of Iran, Report, 27, 1-197.

Zittel, K.A., 1885, Handbuch der Palaeontologie, 1. Abtheilung Palaeozoologie, Band 2, Mollusca and Arthropoda: München and Liepzig, R. Oldenbourg, 525-721. 